\title{
Portable Chamber Measurements of Evapotranspiration at the Amargosa Desert Research Site near Beatty, Nye County, Nevada, 2003-06
}

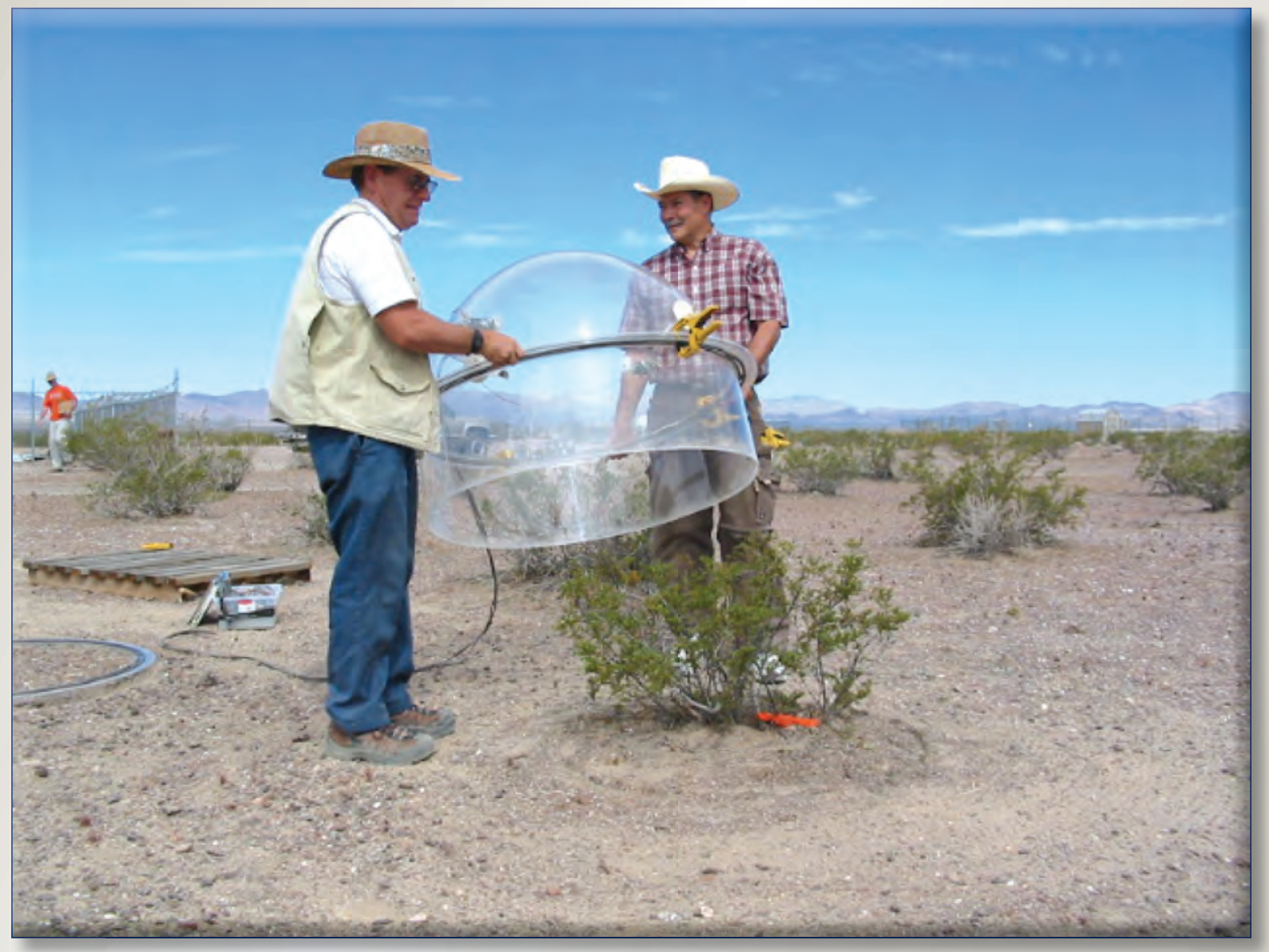

Scientific Investigations Report 2008-5135 
Cover:

Photograph of U.S. Geological Survey field crew, Michael Johnson and Chris

Stone, collecting evapotranspiration measurements using a hemispherical

chamber at the Amargosa Desert Research Site near Beatty, Nye County, Nevada.

(Photograph taken by Brian Andraski, Research Hydrologist, Carson City, Nevada,

2003). 


\section{Portable Chamber Measurements of Evapotranspiration at the Amargosa Desert Research Site near Beatty, Nye County, Nevada, 2003-06}

By C. Amanda Garcia, Michael J. Johnson, Brian J. Andraski, Keith J. Halford, and C. Justin Mayers

Scientific Investigations Report 2008-5135 


\section{U.S. Department of the Interior DIRK KEMPTHORNE, Secretary}

\section{U.S. Geological Survey \\ Mark D. Myers, Director}

\section{U.S. Geological Survey, Reston, Virginia: 2008}

For product and ordering information:

World Wide Web: http://www.usgs.gov/pubprod

Telephone: 1-888-ASK-USGS

For more information on the USGS--the Federal source for science about the Earth, its natural and living resources, natural hazards, and the environment:

World Wide Web: http://www.usgs.gov

Telephone: 1-888-ASK-USGS

Any use of trade, product, or firm names is for descriptive purposes only and does not imply endorsement by the U.S. Government.

Although this report is in the public domain, permission must be secured from the individual copyright owners to reproduce any copyrighted materials contained within this report.

Suggested citation:

Garcia, C.A., Johnson, M.J., Andraski, B.J., Halford, K.J., and Mayers, C.J., 2008, Portable chamber measurements of evapotranspiration at the Amargosa Desert Research Site near Beatty, Nye County, Nevada, 2003-06: U.S. Geological Survey Scientific Investigations Report 2008-5135, 10 p. 


\section{Contents}

Abstract
Introduction
Purpose and Scope
Description of Study Area

Appendix A. Plant Characteristics Including Plant Crown Height, Ratio of Plant Crown Cover to Chamber Area, and Relative-Plant-Crown Cover of Creosote Bush, Shadescale, Burrobush, and Wolfberry at the Amargosa Desert Research Site Near Beatty, Nye County, Nevada, August 2003 through January 2006

Appendix B. Partitioned Bare-Soil Evaporation and Plant Transpiration from Chamber Measurements of Evapotranspiration at the Amargosa Desert Research Site Near Beatty, Nye County, Nevada, January 2003 through January 2006.

Appendix C. Computed Landscape-Scale Evapotranspiration Using Chamber Measurements of Bare-Soil, Creosote Bush, Shadescale, Burrobush, and Wolfberry, and the Fractional Cover of Each Plant Species Across the Landscape at the Amargosa Desert Research Site Near Beatty, Nye County, Nevada, August 2003 through January 2006

\section{Figures}

Figure 1. Map showing location of $(A)$ the Amargosa Desert Research Site (ADRS) near Beatty, Nye County, Nevada, and (B), eddy-covariance station and chamber measurement locations adjacent to the waste-disposal facility

Figure 2. Graph showing time series of vapor density during two consecutive measurements showing best fit lines of the steepest intervals at the Amargosa Desert Research Site near Beatty, Nye County, Nevada, May 1, 2005 ... 4

Figure 3. Graphs showing chamber $(A)$, component-scale evapotranspiration fluxes and net radiation, and $(B)$, total landscape evapotranspiration fluxes at the Amargosa Desert Research Site near Beatty, Nye County, Nevada, May 2, 2005 ... 


\section{Conversion Factors and Datums}

Conversion Factors

\begin{tabular}{lcl}
\hline Multiply & By & To obtain \\
\hline millimeter $(\mathrm{mm})$ & Length & \\
meter $(\mathrm{m})$ & 0.03937 & inch (in.) \\
kilometer $(\mathrm{km})$ & 3.281 & foot $(\mathrm{ft})$ \\
mile $(\mathrm{mi})$
\end{tabular}

Datums

Vertical coordinate information is referenced to the North American Vertical Datum of 1988 (NAVD 88).

Horizontal coordinate information is referenced to the North American Datum of 1983 (NAD 83). 


\title{
Portable Chamber Measurements of Evapotranspiration at the Amargosa Desert Research Site near Beatty, Nye County, Nevada, 2003-06
}

\author{
By C. Amanda Garcia, Michael J. Johnson, Brian J. Andraski, Keith J. Halford, and C. Justin Mayers
}

\begin{abstract}
Portable chamber measurements of evapotranspiration (ET) were made at the U.S. Geological Survey's Amargosa Desert Research Site in southern Nevada to help quantify component- and landscape-scale contributions to ET in an arid environment. Evapotranspiration data were collected approximately every 3 months from 2003 to 2006. Chamber measurements of ET were partitioned into bare-soil evaporation and mixed-species transpiration components. The component-scale ET fluxes from native shrubs typically surpassed those from bare soil by as much as a factor of four. Component-scale ET fluxes were extrapolated to landscapescale ET using a one-layer, multi-component canopy model. Landscape-scale ET fluxes predominantly were controlled by bare-soil evaporation. Bare soil covered 94 percent of the landscape on average and contributed about 70 percent of the landscape-scale vapor flux. Creosote bush, an evergreen shrub, accounted for about 90 percent of transpiration on average due to its dominance across the landscape ( 80 percent of the 6 percent shrub cover) and evergreen character.
\end{abstract}

\section{Introduction}

Evapotranspiration (ET) measurements are essential when quantifying soil-plant-atmosphere controls on hydrologic transport processes in arid environments. Current research at the U.S. Geological Survey's Amargosa Desert Research Site (ADRS), adjacent to a low-level radioactive and hazardous chemical-waste facility, includes analysis of soilplant atmosphere interactions as they relate to transport and release of waterborne contaminants. In support of this ongoing research, the ET components of transpiration and evaporation from distinct plant species and bare soil were differentiated with periodic portable chamber measurements of ET. The components were combined in a one-layer, multi-component canopy model to estimate total landscape-scale ET (Stannard, 1988; Stannard and Weltz, 2006).

Portable chambers have been used to measure ET from cultivated alfalfa fields (Reicosky and others, 1983), bare soil, and sparsely vegetated plant communities (Stannard, 1988; Stannard and Weltz, 2006). Chambers also have been used to determine ET from distinct vegetation types within mixed species communities (Stannard, 1988). Chambers measure the water vapor exchange between the Earth's surface and the atmosphere from small areas (Dugas and others, 1997) by enclosing a known volume of a plant canopy, soil surface, or both, and then measuring the increase in vapor density within the chamber. The maximum rate of change in vapor density with time is proportional to the ET flux from the surface area enclosed by the chamber (Stannard, 1988).

\section{Purpose and Scope}

This report documents the measuring of ET from different desert-shrub species and bare soil using a portable chamber at an arid mixed-vegetation site, partitioning of ET measurements into transpiration and evaporation, and compiling chamber measurements into landscape-scale ET. From 2003 to 2006, chamber ET measurements over creosote bush, shadescale, and bare soil were collected approximately every 3 months; measurements over burrobush and wolfberry were collected annually. Partitioning of chamber ET measurements into evaporation and transpiration components and assembly of these components into landscape-scale ET using a one-layer, multi-component canopy model are described. The magnitude and variability in component- and landscape-scale ET are compared between shrub species and bare soil. 


\section{Description of Study Area}

The ADRS borders a waste-disposal facility in the Mojave Desert, $17 \mathrm{~km}$ southeast of Beatty, Nev., near Death Valley (fig. 1A). The ADRS is in one of the most arid regions of the United States. Annual precipitation averaged

$130 \mathrm{~mm}$ during 2001-05 and was highly variable from month to month and year to year (Johnson and others, 2007). Annual potential evaporation is about 1,900 $\mathrm{mm}$ (Nichols, 1987). The Amargosa Desert in the Basin and Range Province is bounded by lower Paleozoic rock and Tertiary volcanic-rock mountains (Fischer, 1992). Surface soils are mapped as the YermoArizo association. The Yermo soils are loamy-skeletal and the Arizo soils are sandy-skeletal. Subsurface sediments are predominantly fluvial deposits, consisting of several sand and gravel sequences (Andraski, 1996). Depth to the water table ranges from 85 to $115 \mathrm{~m}$ below land surface (Fischer, 1992).

The sparsely vegetated (6-8 percent of the landscape; Andraski and others, 2005) study site is dominated by creosote bush [Larrea tridentata (Sessé \& Moc. Ex DC.) Coville], an evergreen shrub (Smith and others, 1997). The root system of a creosote bush can exceed $4 \mathrm{~m}$ radially (Gile and others, 1998) and the root system depth generally corresponds with the penetration depth of annual precipitation, about 0.75 to $1 \mathrm{~m}$ at the ADRS (Andraski, 1997). Root-zone (0-1 m depth) volumetric soil-water content ranges from 0.02 to $0.12 \mathrm{~m}^{3} / \mathrm{m}^{3}$ and near-surface soil-water content ranges from 0.02 to $0.31 \mathrm{~m}^{3} / \mathrm{m}^{3}$ (2001-05; Johnson and others, 2007). Drought deciduous plant species include shadscale [Atriplex confertifolia (Torr. \& Frém) S. Wats.], burrobush [Ambrosia dumosa (Gray) Payne], and wolfberry [Lycium pallidum Miers].

Portable chamber measurements of ET were collected periodically at locations 1 and 2 shown in figure $1 B$. Site selections were based on four 400-m transects measured in 2001 using the line-transect method (Smith, 1974); and chosen for their proximity to an eddy-covariance ET station (fig. 1B), for representative plant size and shape, and for having replicate plants within close proximity.

\section{Study Design and Methods}

\section{Portable Chamber Construction}

The chamber consists of a 2.4-mm thick, 1-m diameter hemispherical dome made of Plexiglass G (Stannard, 1988). A cylindrical $0.305-\mathrm{m}$ high skirt of similar thickness, diameter, and material typically was added to the bottom of the hemisphere to measure taller plants. The combined hemisphere and cylindrical skirt has a total height of $0.805 \mathrm{~m}$, an internal volume of $0.5 \mathrm{~m}^{3}$, and covers a $0.79 \mathrm{~m}^{2}$ landsurface area. Two 12-volt fans were mounted inside the chamber (about $0.3 \mathrm{~m}$ above the hemisphere base) and positioned opposite each other to keep the air and water vapor well mixed. Internal fan speed was adjusted to approximate the average wind speed at the site. External wind speed was measured using a portable wind gage mounted at one-half the combined chamber and skirt height $(0.4 \mathrm{~m})$ and a rheostat was used to adjust the internal fan speed to match the external wind speed. Between the fans, a temperature and relative humidity probe was used to measure vapor density.

\section{Chamber Measurements of Evapotranspiration}

Chamber measurements at mixed-vegetation sites were collected over approximately 15 -min intervals during daylight hours. Bare-soil evaporation was measured from a single site near the eddy-covariance ET station in January and May 2003, and from two replicate sites at location 1 from August 2003 through January 2006 (fig. 1B). Plant transpiration was measured in conjunction with bare-soil evaporation at location 1. Plant transpiration was measured from replicate creosote bush plants (August 2003 through January 2006) and a single shadescale plant (October 2003 through January 2006). Shrubs from the four primary plant species (creosote bush, shadescale, burrobush, and wolfberry) were measured on three separate occasions at location 2 (May 4, 2004, May 2, 2005, August 4, 2005) (fig. 1B).

The chamber was positioned over soil and plant sites while a data logger collected measurements every 2 seconds for about a 2-min interval. Between measurements, the chamber was raised above the land surface for a minimum of 2 min to obtain ambient humidity and air temperature inside the chamber. Datasets consisting of at least one measurement per site typically were collected within $15 \mathrm{~min}$; datasets were repeated at or greater than hourly intervals.

The evapotranspiration rate was estimated at each soil and plant site using (Stannard, 1988):

$$
E T=86.4 \frac{M V C}{A},
$$

where

$E T$ is the evapotranspiration rate, in millimeters per day,

$M$ is the maximum slope of the vapor density time series, in grams per cubic meter per second,

$V$ is the volume inside the chamber, in cubic meters,

$C$ is the calibration factor of the chamber, unitless,

$A$ is the land-surface area covered by the chamber, in square meters, and

86.4 is a factor that converts grams per cubic meter per second to millimeters per day using the density of water.

Evapotranspiration reported as millimeters per day is an instantaneous rate that occurs at the time of measurement.

The maximum constant-slope section of the vapor density time series was determined using an automated spreadsheet 

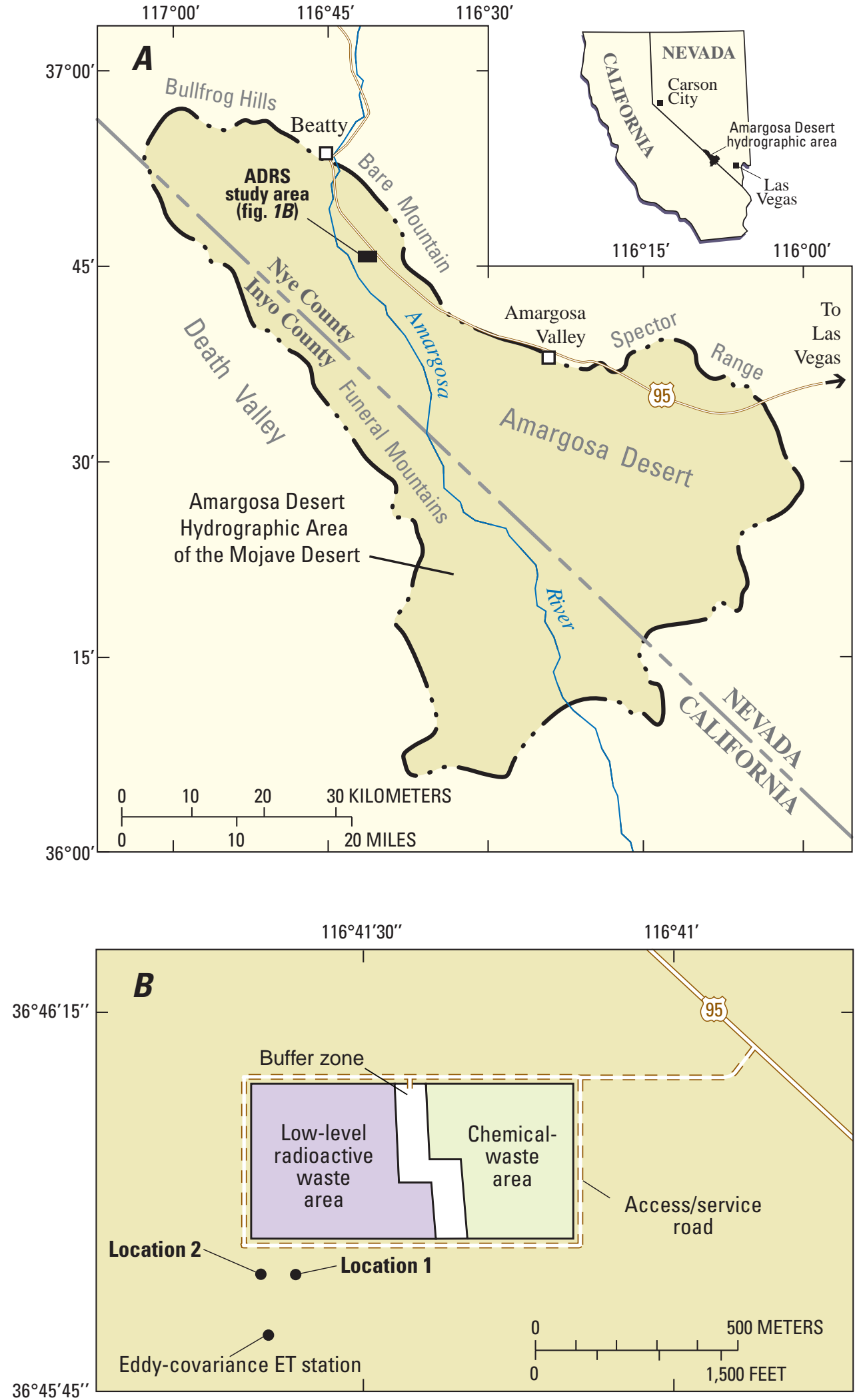

Base from U.S. Geological Survey digital data, 1:100,000, 1978-88 North American Datum of 1983

Figure 1. Location of $(A)$ the Amargosa Desert Research Site (ADRS) near Beatty, Nye County, Nevada, and (B), eddy-covariance station and chamber measurement locations adjacent to the waste-disposal facility. 
program that applied ordinary least-squares analysis within a 10- to 20-second measurement interval. A typical time series of vapor density inside the chamber during two consecutive measurements (creosote bush and bare soil) is shown in figure 2. Beginning with the first 5-10 points on the vapor density curve, the program stepped through the whole curve calculating the slopes while maintaining the same number of points. The final slope selection then was manually verified or adjusted as necessary to represent the best fit line of the steepest time interval. The maximum vapor density slope for creosote bush was measured between 15 and 25 seconds after chamber emplacement while the maximum slope for the bare soil site was reached between 54 and 64 seconds after emplacement.

The chamber calibration factor, which accounted for the slight hydrophilicity of the chamber material, was determined using methods described by Stannard (1988). The procedure involved evaporating a mass of water from a beaker at a known rate and then placing the chamber over the beaker to determine the chamber-measured rate. This procedure was repeated several times at each of the several known evaporation rates. Chamber and known evaporation rates were plotted against one another and the slope of the best fit line through the origin was the calibration factor used (in this case, $C=1.037$ ).

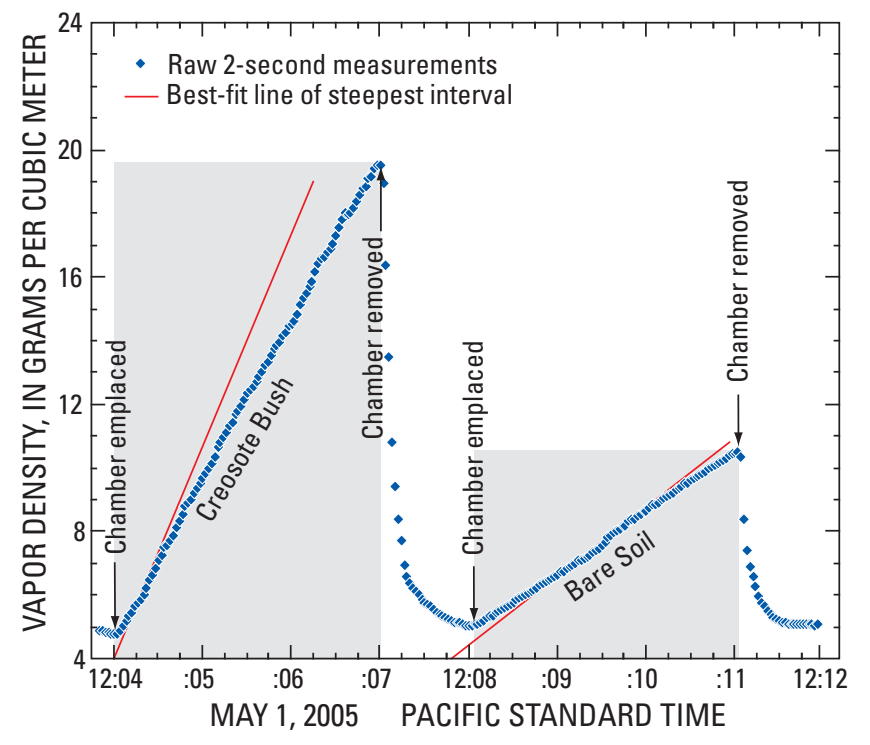

Figure 2. Time series of vapor density during two consecutive measurements showing best fit lines of the steepest intervals at the Amargosa Desert Research Site near Beatty, Nye County, Nevada, May 1, 2005.

\section{Landscape-Scale Evapotranspiration}

Plant and soil ET rates computed from eq. (1) were extrapolated to compute ET on a component- and landscapescale using a one-layer, multi-component model representing a sparse canopy on a planar surface (Stannard, 1988; Stannard and Weltz, 2006):

$$
\begin{aligned}
E T_{l s} & =\sum_{i=1}^{n} F c_{i} \frac{\left[E T_{i}-E_{s}\left(1-R c_{i}\right)\right]}{R c_{i}} \\
& +F c_{u s} \sum_{i=1}^{n} \frac{\left[E T_{i}-E_{s}\left(1-R c_{i}\right)\right]}{R c_{i}}\left(\frac{F c_{i}}{\sum_{i=1}^{n} F c_{i}}\right)+F c_{s} E_{s},
\end{aligned}
$$

where

$E T_{l s}$ is the total landscape-scale ET, in millimeters per day,

$i$ is an index representing each of the measured plant species,

$n$ is the number of measured species,

$F c_{i}$ is the fractional cover of the $i$ th plant species, unitless,

$E T_{i}$ is the site ET flux from the $i$ th plant species, in millimeters per day,

$E_{s}$ is the bare-soil evaporation, in millimeters per day,

$R c_{i}$ is the relative canopy crown cover of the $i$ th plant species within the chamber area, unitless,

$F c_{s}$ is the fractional cover of bare soil, unitless, and

$F c_{u s}$ is the fractional cover of unmeasured plant species, unitless.

The first two terms on the right-hand side of eq. (2) represent landscape-scale transpiration from specific and unmeasured plant species; the last term represents landscapescale evaporation from bare soil. Unmeasured plant species were assigned the average, weighted plant transpiration of measured species. Component-scale transpiration and evaporation fluxes were computed by dividing eq. (2) terms by representative $F c$ values. Negligible transpiration was assumed when $E T_{i}$ was less than or equal to $E_{s}$.

Fractional cover of bare soil and all individual plant species was measured using the line-transect method (Smith, 1974). Four 200-m transects extending outward in the northwest, northeast, southwest, and southeast directions from the eddy-covariance ET station (fig. $1 B$ ) were measured quarterly, representing a $0.16 \mathrm{~km}^{2}$ area. Plant coverage was estimated from additive measurements of the vertical 
projection of plant canopies overlaying line transects. Baresoil coverage comprised gaps between plants and within plant canopies. The $F c_{s}$ was computed as the total coverage of bare soil for all four transects divided by the total transect length $(800 \mathrm{~m}) ; F c_{i}$ and $F c_{u s}$ were computed as the total coverage of an individual plant species for all four transects divided by the total transect length; and $F c_{u s}$ was differentiated for species that were excluded from chamber measurements. During the period of study, non-dormant, leafed shrubs covered 4-10 percent of the landscape.

The relative plant crown cover, $R c$, was estimated using photographs of the measured plant sites and the following equation (Stannard, 1988):

where

$$
R c=\left[\frac{(H-h)}{H}\right]^{2} R c^{\prime},
$$

$H$ is the camera height, in meters (typically $2.13 \mathrm{~m}$ ), $h$ is the height of the major axis of the plant crown, in meters (estimated here as one-half the average plant height for the $i$ th plant species), and

$R c^{\prime}$ is the ratio of plant crown cover to chamber area, unitless (plant crown and chamber area were digitized from digital photographs).

Measured variables $h$ and $R c^{\prime}$ and computed $R c$ are given in appendix A. Average relative crown cover for creosote bush, shadescale, burrobush, and wolfberry was $0.64,0.21,0.27$, and 0.68 , respectively. Evaporation from canopy shaded soil (excluding gaps within plant canopies) was assumed negligible and was not separated from the plant transpiration component.

Chamber ET measurements at location 2 excluded bare soil on all dates and creosote bush in May 2003. Therefore, component-scale evaporation and transpiration fluxes measured the previous day, during a similar time interval at location 1 were substituted in eq. (2).

\section{Evapotranspiration Measurements}

An example time series of component-scale evapotranspiration fluxes (wolfberry, creosote bush, shadescale, burrobush, and bare soil) and net radiation (15-min intervals; Johnson and others, 2007) measured on May 2, 2005 , is shown in figure $3 \mathrm{~A}$. Using plant crown measurements $(R c)$ from appendix A, bare-soil evaporation was subtracted from chamber measurements of ET, yielding transpiration for each species. Cloud cover on May 2, 2005, alternated between
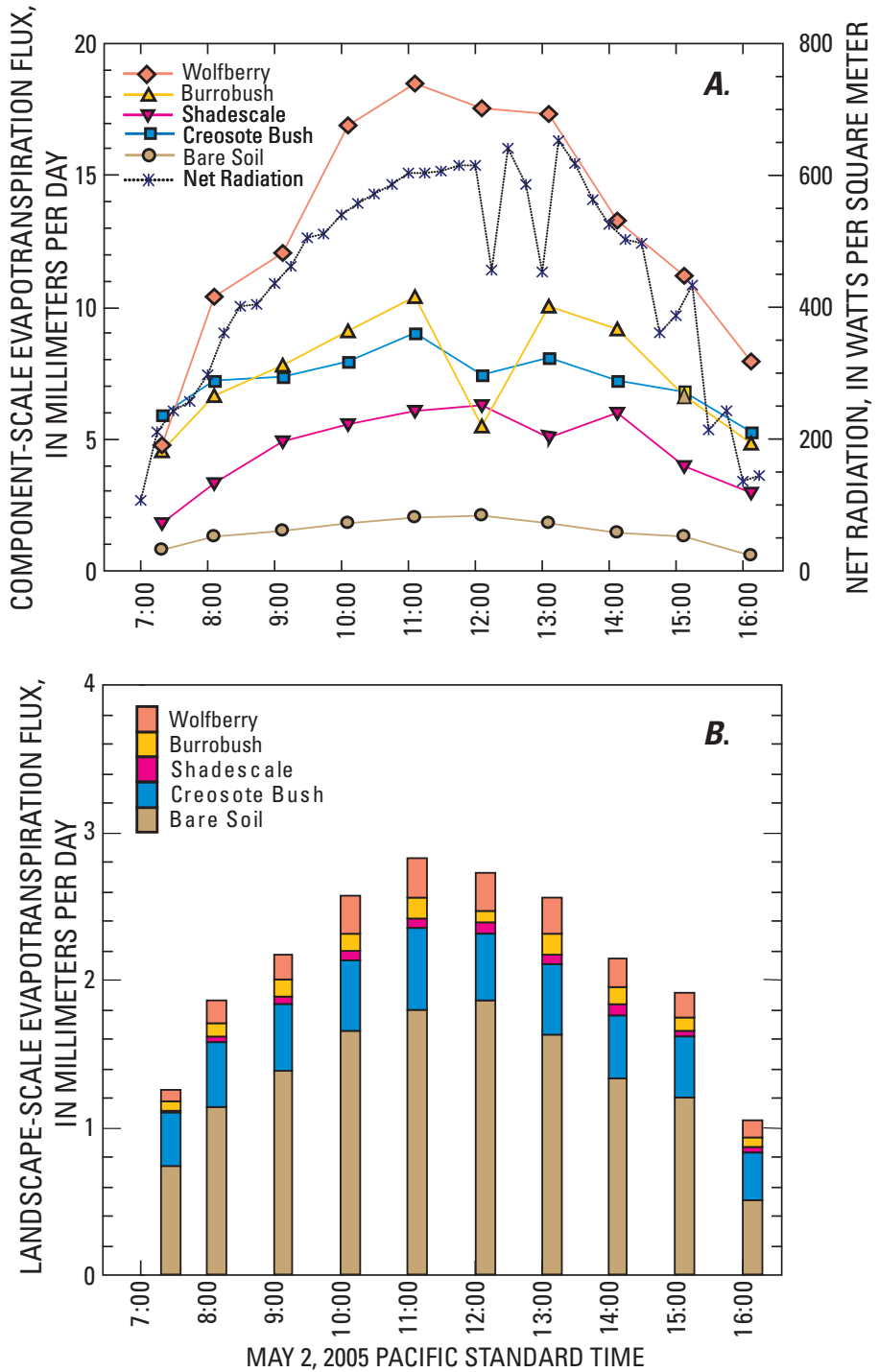

Figure 3. Chamber $(A)$, component-scale evapotranspiration fluxes and net radiation, and $(B)$, total landscape evapotranspiration fluxes at the Amargosa Desert Research Site near Beatty, Nye County, Nevada, May 2, 2005.

Evapotranspiration reported as millimeters per day is an instantaneous rate that occurs at the time of measurement.

partly cloudy and clear. The mean root-zone (0.15-1.0-m depth) soil moisture measured with a neutron probe was $0.06 \pm 0.01 \mathrm{~m}^{3} / \mathrm{m}^{3}$ and was twice the soil moisture $\left(0.03 \mathrm{~m}^{3} / \mathrm{m}^{3}\right.$; Johnson and others, 2007) measured in near surface soils (0-0.08-m depth) using a water-content reflectometer. Net radiation $\left(R_{n}\right)$ and component-scale ET fluxes followed similar patterns reflecting the diurnal solar cycle. 
In addition, substantial fluctuations in 15-min $R_{n}$ measurements occurred during partly cloudy periods (fig. $3 A$ ). Sudden increasing and decreasing $R_{n}$ values (caused by intermittent cloud cover) were reflected in burrobush, creosote bush, and shadscale chamber flux measurements (for example, $R_{n}$ period beginning at 12:00 and 13:15 PST). Although, some variable fluctuations in $R_{n}$ did not correspond to fluctuating ET fluxes (14:30-15:45), most variability affecting short (about 2 min) chamber measurements during intermittent cloud cover was captured by 15 -min $R_{n}$ measurements. Unlike the flux patterns for burrobush, creosote bush, and shadescale, wolfberry and bare-soil chamber fluxes were less sensitive to fluctuations in $R_{n}$ (fig. $3 A$ ), indicating that measurements were likely collected when overhead skies were clear. In addition to $R_{n}$, variability in component-scale ET fluxes measured in May 2005 and during additional quarters (appendix B) occasionally corresponded with lesser factors affecting ET variability (such as air temperature, wind speed, and vapor pressure; data not shown). Erratic chamber fluctuations that did not correspond with measureable weather factors were likely from random noise in the chamber method (Stannard and Weltz, 2006).

Component-scale ET fluxes for vegetation typically were greater than for bare soil and varied by a factor of 1-3 between species on May 2, 2005 (fig. 3A) and by as much as a factor of 4 for all periods measured (appendix B). Creosote bush, which had an $R c$ that was, on average, a factor of 3.5 greater than shadescale (2003-05; appendixes A and $\underline{B}$ ), exhibited the greatest component-scale ET fluxes during summer, autumn, and winter months (except Oct. 2004 and Jan. 2005 when vegetative fluxes were negligible). During the spring when all four plant species were measured, component-scale ET fluxes from wolfberry (which had a high leaf density and the largest $R c$ ) typically were greatest, followed by burrobush and creosote bush (fig. 3A).

An example time-series of landscape-scale ET fluxes (combination of wolfberry, burrobush, creosote bush, shadescale, and bare soil) measured on May 2, 2005, is shown in figure $3 B$. Bare-soil evaporation dominated the total water flux at this scale, despite drier surface soil (twice as dry as the aggregate root zone). Expansive bare-soil cover across the landscape $\left(F c_{s}=0.90\right)$ magnified lower bare-soil fluxes and reduced greater plant fluxes measured on a component scale. Plant transpiration from wolfberry and burrobush, which dominated ET on the component scale (fig. 3A), was minimized when extrapolated to the landscape scale $(F c=$ 0.01 in spring 2005 ; appendix C). At the landscape scale $(F c=$ $0.06)$, transpiration from creosote bush was greater than from wolfberry and burrobush despite having a lower componentscale transpiration than these plant species. On average, transpiration on May 2, 2005, accounted for about 40 percent of total landscape-scale ET. Variation in transpiration fluxes among species at the landscape-scale (a factor of 2-17; fig. $3 B$ ) was substantially greater than the variation for component-scale fluxes (a factor of 1-3; fig. $3 A$ ).
Transpiration accounted for about 30 percent of landscape-scale ET on average and bare-soil evaporation for about 70 percent over all periods measured. Landscape-scale fluxes measured for all periods are given in appendix $\mathrm{C}$. For all measurement periods, bare-soil evaporation was the predominant contributor of moisture loss to the atmosphere as a result of its large landscape cover ( $F c=0.94$ on average). The relative rank of transpiration contributions varied among creosote bush and the three drought deciduous species. Due to its abundance across the landscape ( 80 percent of vegetative cover), creosote bush accounted for about 90 percent of transpiration on average and ranged from about 50 to 100 percent of transpiration for all measurement periods.

\section{Summary}

Portable chamber measurements of ET helped to quantify component-scale and landscape-scale contributions to ET from bare soil and sparsely vegetated, mixed species plant communities. Measurements were collected approximately every 3 months from 2003 to 2006 at the Amargosa Desert Research Site in southern Nevada. Chamber measurements of the four primary plant species and bare soil were combined in a one-layer, multi-component canopy model to estimate (1) transpiration and evaporation components from individual plant species and bare soil, respectively, and (2) landscapescale ET. Although chamber measurements of ET from native shrubs typically surpassed those from bare soil, soil evaporation dominated landscape-scale ET during all periods measured.

Component-scale chamber ET from vegetation typically was greater and more variable throughout a given day than that from bare soil. Variability in net radiation and other factors affecting ET were more notably reflected in 15-min chamber measurements from vegetation than from bare soil. Creosote bush typically exhibited the greatest chamber ET fluxes during summer, autumn, and winter as a result of its evergreen character and high relative-plant-crown cover. During spring when all four plant species were measured, component-scale ET fluxes from wolfberry typically were greatest as a result of its high leaf density, followed by burrobush and creosote bush.

Landscape-scale ET fluxes predominantly were controlled by bare-soil evaporation; bare soil covered 94 percent of the landscape on average. Sparsely distributed vegetation ( 6 percent of the landscape), in turn, caused the relative importance of creosote bush and other plant species to be substantially overwhelmed. Due to its abundance across the landscape ( 80 percent of vegetative cover), creosote bush accounted for about 90 percent of transpiration on average and ranged from about 50 to 100 percent of transpiration for all measurement periods. Overall, transpiration accounted for about 30 percent of ET on average and bare-soil evaporation for 70 percent. 


\section{References Cited}

Andraski, B.J., 1996, Properties and variability of soil and trench fill at an arid waste-burial site: Soil Science Society of America Journal, v. 60, p. 54-66.

Andraski, B.J., 1997, Soil-water movement under natural-site and waste-site conditions-A multiple-year field study in the Mojave Desert, Nevada: Water Resources Research, v. 33, p. 1901-1916.

Andraski, B.J., Stonestrom, D.A., Michel, R.L., Halford, K.J., and Radyk, J.C., 2005, Plant-based plume-scale mapping of tritium contamination in desert soils: Vadose Zone Journal, v. 4, p. 819-827, accessed June 10, 2008, at http://vzj. scijournals.org/cgi/reprint/4/3/819

Dugas, W.A., Reicosky, D.C., and Kiniry, J.R., 1997, Chamber and micrometeorological measurements of $\mathrm{CO}_{2}$ and $\mathrm{H}_{2} \mathrm{O}$ fluxes for three $\mathrm{C}_{4}$ grasses: Agricultural and Forest Meteorology, v. 83, p. 113-133.

Fischer, J.M., 1992, Sediment properties and water movement through shallow unsaturated alluvium at an arid site for disposal of low-level radioactive waste near Beatty, Nye County, Nevada: U.S. Geological Survey Water-Resources Investigations Report 92-4032, 48 p.

Gile, L.H., Gibbens, R.P., and Lenz, J.M., 1998, Soilinduced variability in root systems of creosotebush (Larrea tridentate) and tarbush (Flourensia cernua): Journal of Arid Environments, v. 39, p. 57-78.
Johnson, M.J., Mayers, C.J., Garcia, C.A., and Andraski, B.J., 2007, Selected micrometeorological, soil-moisture, and evapotranspiration data at Amargosa Desert Research Site in Nye County near Beatty, Nevada, 2001-05: U.S. Geological Survey Data Series 284, 28 p., accessed October 26, 2007 , at http://pubs.usgs.gov/ds/2007/284/

Nichols, W.D., 1987, Geohydrology of the unsaturated zone at the burial site for low-level radioactive waste near Beatty, Nye County, Nevada: U.S. Geological Survey Water-Supply Paper 2312, p. 57-78.

Reicosky, D.C., Sharratt, B.S., Ljungkull, J.E., and Baker, D.G., 1983, Comparison of alfalfa evapotranspiration measured by a weighing lysimeter and a portable chamber: Agricultural Meteorology, v. 28, p. 205-211.

Smith, R.L., 1974, Ecology and field biology (2 ${ }^{\text {nd }}$ ed.): New York, Harper and Row.

Smith, S.D., Monson, R.K., and Anderson, J.E., 1997, Physiological ecology of North American desert plants: Berlin, Springer-Verlag, 286 p.

Stannard, D.I., 1988, Use of a hemispherical chamber for measurement of evapotranspiration: U.S. Geological Survey Open-File Report 88-452.

Stannard, D.I., and Weltz, M.A., 2006, Partitioning evapotranspiration in sparsely vegetated rangeland using a portable chamber: Water Resources Research, v. 42, doi:10.1029/2005WR004251. 
This page intentionally left blank. 


\section{Appendixes}

Data files that contain plant characteristics (appendix A) and the complete chamber component- and landscape-scale ET flux measurements (appendixes B and C) are presented in three spreadsheets in a Microsoft $\odot$ Excel workbook. The appendixes can be accessed and downloaded at URL http://pubs.usgs.gov/sir/2008/5135/sir20085135 appendixes.xls

Appendix A. Plant Characteristics Including Plant Crown Height, Ratio of Plant Crown Cover to Chamber Area, and Relative-PlantCrown Cover of Creosote Bush, Shadescale, Burrobush, and Wolfberry at the Amargosa Desert Research Site Near Beatty, Nye County, Nevada, August 2003 through January 2006.

Appendix B. Partitioned Bare-Soil Evaporation and Plant Transpiration from Chamber Measurements of Evapotranspiration at the Amargosa Desert Research Site Near Beatty, Nye County, Nevada, January 2003 through January 2006.

Appendix C. Computed Landscape-Scale Evapotranspiration Using Chamber Measurements of Bare-Soil, Creosote Bush, Shadescale, Burrobush, and Wolfberry, and the Fractional Cover of Each Plant Species Across the Landscape at the Amargosa Desert Research Site Near Beatty, Nye County, Nevada, August 2003 through January 2006. 
This page intentionally left blank. 
For more information concerning the research in this report, contact the Director, Nevada Water Science Center

U.S. Geological Survey

2730 N. Deer Run Road

Carson City, Nevada 89701

http://nv.water.usgs.gov 
